\title{
Incorporating Anthropometry into Design of Products
}

\author{
Bor-Shong Liu ${ }^{1}$ and Ching-Wen Lien ${ }^{2}$ \\ ${ }^{1}$ Department of Industrial Engineering and Management, \\ St. John's University, Tamsui, New Taipei City, \\ ${ }^{2}$ Nursing Department, Taipei Veterans General Hospital, Taipei \\ Taiwan
}

\section{Introduction}

To achieve mass customization and collaborative product design, human factors and ergonomics should play a key development role. In population, accommodation, sizing has been aimed at improving the product to either get better fit, or broaden the range of befitting users (Li, 2006; Nui et al., 2006). Thus, anthropometry is considered the very ergonomic core of any attempt to resolve the dilemma of 'fitting the tasks to the human' (Sanders and McCormick, 1993). As products are designed for specific types of consumers, an important design requirement is selection and efficient utilization of the most appropriate anthropometric database (Wickens et al., 2004). Great effort has been expended conducting numerous surveys to establish anthropometric databases for different population groups such as the armed forces, students, civilians, and farm workers (Mououdi, 1997; Wang et al., 1999). These anthropometric data sets provide critical design information for an enormous range of ergonomics-based tasks such as workplace design (Wang et al., 1999), and sizing for clothes (Meunier and Yin, 2000) and school furniture (Milanese and Grimmer, 2004). Effective utilization of this data, however, requires a thorough analysis of the inherent design problems on the designers' part. Wickens et al. (2004) adopted a systematic approach to utilization of anthropometric data in design, principally through: (1) determination of the target population (the intended users); (2) determination of the relevant physical dimensions; (3) determination of the percentage of the population to be accommodated; (4) determination of the ideal percentile value for the selected anthropometric dimension; (5) incorporation of the necessary design modifications based on this anthropometric data; and, (6) use of mock-ups or simulators to test the design. Thus, key design issues include identification of the target user groups and identification of the most important bodily dimensions. Two cases were presented in this chapter as design for baby diaper, and spoon of children.

\section{Case 1: Diaper wearing and fitness of sizing system for infants}

\subsection{Introduction}

Standard sizing systems of garment are very crucial issue, play an even important role for garment manufacturing industry. Under traditional production procedures, garment 
manufacturers have never developed standard sizing systems for the market, finally resulting in heavy stock burden to garment manufacturers. Standard sizing systems can correctly predict numbers of items and ratio of sizes to be produced, resulting in accurate inventory control and production planning (Hsu et al., 2007).

In late nineteenth century, infants in Europe and North America were wearing the progenitor of the modern diaper. A square of rectangle of linen, cotton flannel, or stockinet was folded into a rectangular shape and held in place with safety pins. The first disposable absorbent pad used as a diaper was probably the one made from unbleached creped cellulose tissue (held in rubber pants) in 1942 by Paulistróm in Sweden, maybe because cotton had become a strategic material due to the war effort. A few years later in 1946, in the United States, a Westport housewife named Marion Donovan, invented the "Boater", a waterproof covering for cloth diapers. Her first model of the disposable diaper was made of shower curtain plastic into which a conventional cloth diaper was inserted. Recent years have brought many improvements to disposable diapers. The disposable diaper evolves quickly. Instead of tissue, a pulp mill was introduced. Using cellulose fibers instead of paper, improved the performance of the diaper. On the other hand, the diaper dermatitis or diaper rash is probably the most common cutaneous disorders of infancy and early childhood. Presence of ammonia caused by bacterial breakdown of urea in the child's urine was believed to be a major factor in the etiology of diaper dermatitis (Jackson, 1995). Although friction of skin-to-skin and skin-to-diaper is not a dominant factor, it may be an important predisposing factor (Wolf et al., 2000). Thus, customers show much concern about picking the diaper for ensuring a perfect fit with their infants.

Diapers are commonly worn from birth until a person is toilet trained. Diapers evolved in the 1960s from a double layer of cotton folded into a triangle and attached with safety pins to products that include a top sheet of plastic and cellulose pulp core. More recently, the core was changed to gel for its absorbency potential. Product innovations include the use of superabsorbent polymers, re-sealable tapes and elastic waist bands. Gel also prevents skin from becoming super hydrated, and as a result diaper rash has been on the decline in recent decades. However, it still occurs, and in most cases, diaper dermatitis is caused by the diaper itself (Gorgos, 2006). Diaper rash or diaper dermatitis is one of the most common skin disorders in infants and toddlers (Liptak, 2001). The etiology is multifocal and a diaper rash may present in various conditions in the pediatric community (Borkowski, 2004). Diaper dermatitis usually occurs as a primary reaction to irritation by urine, feces, moisture, or friction (Van Onselen, 1999). Distribution patterns may vary, but irritative dermatitis typically involves the convex surfaces where the skin is in greatest contact with the diaper. Irritative dermatitis usually spares the inquinal folds, and may be mild red, shiny, and with or without papules (Liptak, 2001; Wysocki and Bryant, 1992).

Thus, care and management of diaper dermatitis can present a challenge for pediatric nurses and care providers. Prevention of diaper rash is achieved through maintenance of skin integrity to prevent damage to the stratum corneum, the skin's barrier. Keeping the baby dry, which entails frequent diaper change, is the ideal way to both treat and prevent irritant diaper dermatitis (Jorden et al., 1986). Diapers should be changed and the area cleaned and allowed to dry as soon as possible after soiling or wetting. The skin should be exposed to the open air for 5 to 10 minutes following each diaper change. The use of plastic pants should be avoided or at least limited and diapers should not be too tight. Changing of diaper brands 
may be considered with chronic diaper rash breakouts. Irritants should be avoided or removed by washing with warm water and cotton balls and patting dry.

In addition, the argument has been that diaper type (cloth versus paper) is an important factor in controlling the spread of fecal material and therefore a major contributor to the spread of enteric pathogens in the environment (Kubiak et al., 1993). Previous studies have suggested that paper diapers are more effective than cloth diapers in constraining fecal spread (Kubiak et al., 1993; Van et al., 1991). Apart from diaper types, and materials, the sizing system of diaper is another important factor for wearing comfortable. However, the sizing systems of disposable diaper are divided into stages and sold based on three distinct groupings in Seaddlers, Cruisers and Baby Dry (e.g., Pampers Diapers). The sizing systems of diaper are only classified according to growing stage and infants' weigh (Table 1). If an infant is six months with weight of seven $\mathrm{kg}$, how should pick the diaper size to coordinate with her or him (Size 1: Small or Size 2: Medium?). Obviously, selection of diaper size for infants is a problem for parents and care providers.

\begin{tabular}{ccc}
\hline Diaper Cover Size & Age & Weight \\
\hline Newborn, NB & NB & NB-4.5 kg $(10 \mathrm{lb})$ \\
\hline SIZE 1, Small $(\mathrm{S})$ & 0 - 3 months & $4-6 \mathrm{~kg}(8-14 \mathrm{lb})$ \\
\hline SIZE 2, Medium $(\mathrm{M})$ & 2 - 6 months & $5-8 \mathrm{~kg}(12-28 \mathrm{lb})$ \\
\hline SIZE 3, Large (L) & 3 - 12 months & 7-13 kg $(16-28 \mathrm{lb})$ \\
\hline SIZE 4, Extra Large (XL) & 9 -24 months & $10-17 \mathrm{~kg}(22-37 \mathrm{lb})$ \\
\hline SIZE 5, Super Large (SL) & 2.5-4 years & $12+\mathrm{kg}(27+\mathrm{lb})$ \\
\hline SIZE 6 Training & 3.5-7 years & $16+\mathrm{kg}(35+\mathrm{lb})$ \\
\hline
\end{tabular}

Table 1. Diaper sizing systems

A garment sizing systems are used to fit different groups of the population based on demographic anthropometric data. Persons of the same subgroup have the same body shape characteristics, and share the same garment size (Ashdown, 1998; Chung et al., 2007). With the difference in body dimensions and morphological characteristics, different body shapes can be generalized to a few figure types (Ray et al., 1995). Emanuel et al. (1959) recommended the use of the difference in figure types as the classification of ready-towears, and developed a set of procedures to formulate standard sizes for all figure types. According to this system, people of all figure types were first classified into one of four body weight groups (i.e. super heavy, heavy, normal, light. These body weight groups are further subdivided by stature (i.e. tall and short). People were, thus, divided into eight categories based on similar heights and weights.

Furthermore, the purpose of this study was to provide product designs with the anthropometric dimensions of baby and children and analyze along with demographic data, including age. The second purpose was to understand the diaper wearing problems and evaluate the fitness of size system for infants to compare the dimensions of various diapers with anthropometric database and recommend appropriate solutions for design. 


\subsection{Methods}

\subsubsection{Subjects}

Three hundred subjects who aged from newborn to 3 years old were separated into eight stratifications (i.e. under one month, 1-3 months, 3-5 months, 5-7 months, 7-9 months, 9-12 months, 1-2 years, and 2-3 years old) for further analysis. Registered nurses in Tamsui Health Center have conducted the anthropometric survey.

\subsubsection{Methodology of measurement}

Altogether six anthropometric characteristics were measured (Figure 1).
a. Stature;
b. Head circumference;
c. Waist circumference;
d. Buttocks circumference;
e. Thigh circumference;
f. Body weight.

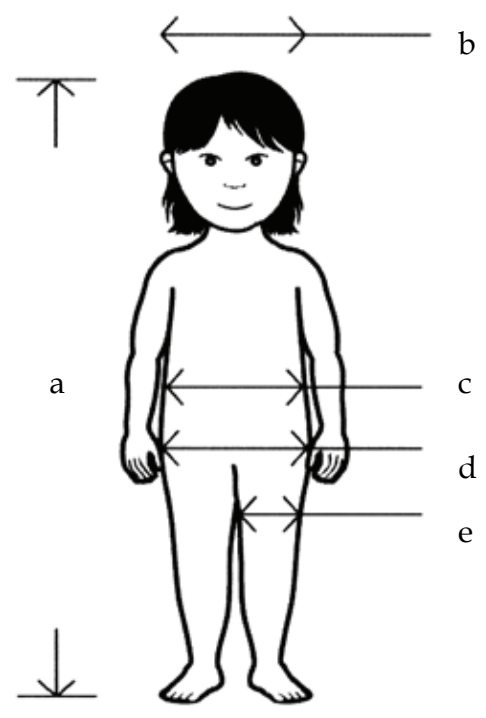

Fig. 1. Anthropometric measurements

\subsubsection{Data analysis}

All data were coded and summarized using SPSS software for Windows. One-way analysis of variance (ANOVA) was used to investigate the effects of age on dimensions of infants. Where statistically significant differences were determined, the Duncan post hoc test was performed. In addition, the relationships between dimensions were assessed from correlation analysis. 


\subsection{Results}

\subsubsection{Effect of age on dimensions}

The ANOVA results for the relationships between dimensions and age are presented in Table 2. All mean dimensions were significant differences between age group $(p<0.001)$. Further, Duncan's post hoc tests revealed that mean stature could be divided into seven subsets $(p<0.05)$. Mean stature were the shortest for the age under one month $(51.7 \mathrm{~cm})$, followed, in ascending order, by the $1-3$ months $(56.8 \mathrm{~cm}), 3-5$ months $(62.4 \mathrm{~cm})$ and $5-7$ months $(64.9 \mathrm{~cm}), 7-9$ months $(69.2 \mathrm{~cm}), 9-12$ months $(72.4 \mathrm{~cm}), 1-2$ years $(81.0 \mathrm{~cm}), 2-3$ years old $(88.6 \mathrm{~cm})$. Mean head circumference were the shortest for the age under one month (35.6 $\mathrm{cm})$, followed, in ascending order, by the 1-3 months $(38.5 \mathrm{~cm}), 3-5$ months $(40.2 \mathrm{~cm}), 5-7$ months $(41.5 \mathrm{~cm}), 7-9$ months $(43.2 \mathrm{~cm})$ and 9-12 months $(44.3 \mathrm{~cm}), 1-2$ years $(46.5 \mathrm{~cm}), 2-3$ years old $(48.7 \mathrm{~cm})$. The mean waist circumference were also lowest for age under one month $(34.6 \mathrm{~cm})$, followed, in ascending order, by the 1-3 months $(38.7 \mathrm{~cm}), 3-5$ months $(41.8$ $\mathrm{cm})$, 5-7 months $(43 \mathrm{~cm}), 7-9$ months $(44.9 \mathrm{~cm}), 9-12$ months $(46.5 \mathrm{~cm}), 1-2$ years $(47.2 \mathrm{~cm}), 2-3$ years old $(49.5 \mathrm{~cm})$. In addition, mean buttocks circumference could be divided into six subgroups $(\mathrm{p}<0.05)$. The mean buttocks circumference were also lowest for age under one month $(32.7 \mathrm{~cm})$, followed, in ascending order, by the 1-3 months $(39.5 \mathrm{~cm}), 3-5$ months $(43.5$ $\mathrm{cm})$, 5-7 months $(43.6 \mathrm{~cm}), 7-9$ months $(47.4 \mathrm{~cm}), 9-12$ months $(48.3 \mathrm{~cm}), 1-2$ years $(50.5 \mathrm{~cm})$, 2-3 years old $(53.1 \mathrm{~cm})$. The mean thigh circumference could stratify six subgroups: subgroup 1 (age under one month, $16.7 \mathrm{~cm})$, subgroup 2 (1-3 months $(20.3 \mathrm{~cm}), 3-5$ months $(21.7 \mathrm{~cm}))$, subgroup $3(3-5$ months $(21.7 \mathrm{~cm}), 5-7$ months $(21.9 \mathrm{~cm}))$, subgroup $4(7-9$ months $(23.4 \mathrm{~cm}), 9-12$ months $(23.9 \mathrm{~cm}))$, subgroup $5(1-2$ years $(26 \mathrm{~cm}))$, and subgroup $6(2-3$ years old, $28.3 \mathrm{~cm}$ ). Finally, the mean body weight could stratify seven subgroups: subgroup 1

\begin{tabular}{|c|c|c|c|c|c|c|}
\hline & Source & $\begin{array}{c}\text { Sum of } \\
\text { squares }\end{array}$ & d.f. & Mean squares & F & $\mathrm{p}$ \\
\hline \multirow{2}{*}{ Stature } & Between groups & 37323.9 & 7 & 5331.9 & 165.5 & 0.001 \\
& Within groups & 9406.5 & 292 & 32.2 & & \\
& Total & 46730.4 & 299 & & & \\
\hline \multirow{2}{*}{ Head } & Between groups & 4170.4 & 7 & 595.7 & 110.3 & 0.001 \\
circumference & Within groups & 1585.4 & 292 & 5.4 & & \\
& Total & 5755.8 & 299 & & & \\
\hline \multirow{2}{*}{ Waist } & Between groups & 4643.4 & 7 & 663.3 & 43.1 & 0.001 \\
circumference & Within groups & 4521.7 & 292 & 15.4 & & \\
& Total & 9165.1 & 299 & & & \\
\hline \multirow{2}{*}{ Buttocks } & Between groups & 8176.4 & 7 & 1168.0 & 98.2 & 0.001 \\
circumference & Within groups & 6194.0 & 292 & 21.2 & & \\
& Total & 14370.4 & 299 & & & \\
\hline \multirow{2}{*}{ Thigh } & Between groups & 2692.1 & 7 & 384.5 & 41.5 & 0.001 \\
circumference & Within groups & 2461.5 & 292 & 8.4 & & \\
& Total & 5153.6 & 299 & & & \\
\hline \multirow{2}{*}{ Weight } & Between groups & 2184.7 & 7 & 312.1 & 148.6 & 0.001 \\
& Within groups & 630.2 & 292 & 2.1 & & \\
& Total & 2814.9 & 299 & & & \\
\hline
\end{tabular}

Table 2. ANOVA of dimensions on age group 


\begin{tabular}{|c|c|c|c|c|c|c|c|c|c|c|c|}
\hline & \multirow{2}{*}{$\begin{array}{c}\text { Age } \\
\text { Group * }\end{array}$} & \multirow{2}{*}{$\mathrm{N}$} & \multirow{2}{*}{ Mean** } & \multirow{2}{*}{ SD } & \multicolumn{7}{|c|}{ Percentile } \\
\hline & & & & & 5 th & 10th & 25th & 50 th & 75th & 90th & 95th \\
\hline \multirow{8}{*}{$\begin{array}{c}\text { Stature } \\
(\mathrm{cm})\end{array}$} & 1 & 14 & $51.7 \mathrm{a}$ & 2.7 & 48.0 & 48.0 & 48.8 & 52.2 & 54.2 & 55.5 & 55.5 \\
\hline & 2 & 31 & $56.8 \mathrm{~b}$ & 4.9 & 46.6 & 49.2 & 54.5 & 57.0 & 61.0 & 62.8 & 64.0 \\
\hline & 3 & 30 & $62.4 \mathrm{c}$ & 6.1 & 51.4 & 54.1 & 58.0 & 63.5 & 66.0 & 71.8 & 73.3 \\
\hline & 4 & 24 & $64.9 c$ & 5.6 & 57.0 & 57.1 & 58.3 & 66.0 & 69.1 & 72.0 & 74.5 \\
\hline & 5 & 37 & $69.2 \mathrm{~d}$ & 5.2 & 59.0 & 61.6 & 65.5 & 70.0 & 72.7 & 76.2 & 79.2 \\
\hline & 6 & 30 & $72.4 \mathrm{e}$ & 5.4 & 62.5 & 65.0 & 68.0 & 72.7 & 76.5 & 80.0 & 80.4 \\
\hline & 7 & 85 & $81.0 \mathrm{f}$ & 5.3 & 71.3 & 74.0 & 78.0 & 82.0 & 84.5 & 88.4 & 90.0 \\
\hline & 8 & 49 & $88.6 \mathrm{~g}$ & 7.1 & 73.0 & 79.0 & 84.5 & 89.0 & 94.0 & 97.0 & 98.0 \\
\hline \multirow{8}{*}{$\begin{array}{c}\text { Head } \\
\text { circumference } \\
(\mathrm{cm})\end{array}$} & 1 & 14 & $35.6 \mathrm{a}$ & 5.4 & 31.0 & 31.5 & 32.0 & 34.5 & 36.7 & 45.0 & 45.0 \\
\hline & 2 & 31 & $38.5 \mathrm{~b}$ & 2.0 & 36.0 & 36.0 & 36.5 & 38.5 & 40.0 & 41.8 & 43.0 \\
\hline & 3 & 30 & $40.2 \mathrm{c}$ & 2.1 & 35.3 & 37.0 & 39.3 & 40.5 & 42.0 & 42.9 & 43.1 \\
\hline & 4 & 24 & $41.5 \mathrm{~d}$ & 2.1 & 38.0 & 38.3 & 40.0 & 41.7 & 43.2 & 44.1 & 44.8 \\
\hline & 5 & 37 & $43.2 \mathrm{e}$ & 2.4 & 38.0 & 40.0 & 42.2 & 43.0 & 44.5 & 46.4 & 48.1 \\
\hline & 6 & 30 & $44.3 \mathrm{e}$ & 2.1 & 40.8 & 42.0 & 43.0 & 44.0 & 45.1 & 47.9 & 49.3 \\
\hline & 7 & 85 & $46.5 \mathrm{f}$ & 1.9 & 43.0 & 43.7 & 45.0 & 46.0 & 48.0 & 49.2 & 50.0 \\
\hline & 8 & 49 & $48.7 \mathrm{~g}$ & 1.7 & 46.0 & 46.5 & 48.0 & 49.0 & 50.0 & 51.0 & 52.0 \\
\hline \multirow{8}{*}{$\begin{array}{c}\text { Waist } \\
\text { circumference } \\
(\mathrm{cm})\end{array}$} & 1 & 14 & $34.6 \mathrm{a}$ & 2.3 & 31.0 & 31.2 & 32.0 & 35.1 & 37.0 & 37.4 & 37.4 \\
\hline & 2 & 31 & $38.7 \mathrm{~b}$ & 2.4 & 36.0 & 36.1 & 37.0 & 38.0 & 40.0 & 42.8 & 44.8 \\
\hline & 3 & 30 & $41.8 \mathrm{c}$ & 5.3 & 34.6 & 36.1 & 38.6 & 40.0 & 42.5 & 50.0 & 55.4 \\
\hline & 4 & 24 & $43.0 \mathrm{~cd}$ & 5.3 & 36.0 & 36.3 & 38.0 & 42.6 & 46.7 & 50.9 & 51.7 \\
\hline & 5 & 37 & 44.9 de & 5.0 & 36.9 & 37.0 & 40.7 & 45.0 & 49.2 & 51.2 & 52.3 \\
\hline & 6 & 30 & 46.5 ef & 3.3 & 40.8 & 42.1 & 43.6 & 46.5 & 49.0 & 51.8 & 52.4 \\
\hline & 7 & 85 & $47.2 \mathrm{f}$ & 3.2 & 40.3 & 44.0 & 45.0 & 47.0 & 49.0 & 51.5 & 52.7 \\
\hline & 8 & 49 & $49.5 \mathrm{~g}$ & 3.6 & 43.0 & 44.0 & 47.8 & 49.5 & 52.0 & 55.0 & 56.0 \\
\hline \multirow{8}{*}{$\begin{array}{c}\text { Buttocks } \\
\text { circumference } \\
(\mathrm{cm})\end{array}$} & 1 & 14 & $32.7 \mathrm{a}$ & 3.6 & 27.0 & 27.5 & 29.6 & 32.0 & 36.0 & 38.1 & 38.1. \\
\hline & 2 & 31 & $39.5 \mathrm{~b}$ & 2.5 & 36.5 & 37.0 & 37.5 & 39.0 & 42.0 & 43.0 & 45.2 \\
\hline & 3 & 30 & $43.5 \mathrm{c}$ & 6.3 & 34.9 & 38.0 & 39.0 & 42.0 & 46.2 & 55.0 & 57.8 \\
\hline & 4 & 24 & $43.6 \mathrm{c}$ & 5.5 & 35.8 & 36.0 & 38.7 & 43.5 & 48.5 & 51.0 & 53.2 \\
\hline & 5 & 37 & $47.4 \mathrm{~d}$ & 6.0 & 36.9 & 39.6 & 42.2 & 48.0 & 52.5 & 55.2 & 57.1 \\
\hline & 6 & 30 & $48.3 \mathrm{df}$ & 4.1 & 42.5 & 43.0 & 44.7 & 48.0 & 51.0 & 54.9 & 56.8 \\
\hline & 7 & 85 & $50.5 \mathrm{f}$ & 3.9 & 43.6 & 46.0 & 47.7 & 50.0 & 53.0 & 56.0 & 58.0 \\
\hline & 8 & 49 & $53.1 \mathrm{~g}$ & 4.1 & 46.3 & 48.0 & 50.6 & 53.0 & 55.1 & 58.0 & 61.0 \\
\hline \multirow{8}{*}{$\begin{array}{c}\text { Thigh } \\
\text { circumference } \\
(\mathrm{cm})\end{array}$} & 1 & 14 & $16.7 \mathrm{a}$ & 2.3 & 13.0 & 13.2 & 14.7 & 17.3 & 18.4 & 20.1 & 20.1 \\
\hline & 2 & 31 & $20.3 \mathrm{~b}$ & 3.2 & 16.0 & 16.0 & 18.0 & 20.0 & 23.5 & 25.0 & 26.0 \\
\hline & 3 & 30 & $21.7 \mathrm{bc}$ & 2.9 & 16.4 & 18.1 & 20.0 & 21.0 & 23.8 & 25.2 & 27.8 \\
\hline & 4 & 24 & $21.9 \mathrm{c}$ & 2.9 & 17.0 & 17.5 & 20.0 & 22.0 & 24.0 & 25.0 & 28.7 \\
\hline & 5 & 37 & $23.4 \mathrm{~d}$ & 2.6 & 19.9 & 20.0 & 21.2 & 23.0 & 25.0 & 27.6 & 28.3 \\
\hline & 6 & 30 & $23.9 \mathrm{~d}$ & 1.7 & 21.1 & 22.0 & 22.0 & 24.0 & 25.5 & 26.0 & 26.5 \\
\hline & 7 & 85 & $26.0 \mathrm{e}$ & 3.1 & 20.1 & 22.3 & 24.0 & 26.0 & 28.3 & 30.0 & 30.7 \\
\hline & 8 & 49 & $28.3 \mathrm{f}$ & 3.1 & 23.6 & 25.0 & 25.9 & 28.5 & 31.0 & 32.4 & 34.0 \\
\hline
\end{tabular}




\begin{tabular}{|c|c|c|c|c|c|c|c|c|c|c|c|}
\hline & \multirow{2}{*}{$\begin{array}{c}\text { Age } \\
\text { Group * }\end{array}$} & \multirow{2}{*}{$\mathrm{N}$} & \multirow{2}{*}{ Mean** } & \multirow{2}{*}{ SD } & \multicolumn{7}{|c|}{ Percentile } \\
\cline { 6 - 10 } & 1 & 14 & $3.3 \mathrm{a}$ & 0.6 & 2.4 & 2.4 & 3.0 & 3.3 & 3.6 & 4.5 & 4.5 \\
& 2 & 31 & $5.4 \mathrm{~b}$ & 1.0 & 4.0 & 4.1 & 4.7 & 5.4 & 6.0 & 6.7 & 7.8 \\
& 3 & 30 & $6.9 \mathrm{c}$ & 1.5 & 3.8 & 5.1 & 6.0 & 6.9 & 7.9 & 8.8 & 10.7 \\
Weight & 4 & 24 & $7.2 \mathrm{c}$ & 1.1 & 5.8 & 6.0 & 6.3 & 7.0 & 7.9 & 9.2 & 10.0 \\
$(\mathrm{Kg})$ & 5 & 37 & $8.1 \mathrm{~d}$ & 1.4 & 6.0 & 6.1 & 7.0 & 8.0 & 9.2 & 10.1 & 11.2 \\
& 6 & 30 & $9.0 \mathrm{e}$ & 1.2 & 7.2 & 7.5 & 8.1 & 8.7 & 10.0 & 10.7 & 11.4 \\
& 7 & 85 & $10.9 \mathrm{f}$ & 1.6 & 8.6 & 9.0 & 10.0 & 10.6 & 12.0 & 13.0 & 14.0 \\
& 8 & 49 & $13.0 \mathrm{~g}$ & 1.7 & 10.0 & 11.0 & 12.0 & 13.0 & 14.7 & 15.0 & 16.0 \\
\hline
\end{tabular}

*Age group: 1:under one month; 2: 1-3 months; 3: 3-5 months; 4: 2-7 months; 5: 7-9 months; 6: 9-12 months; 7: 1-2 years; $8: 2-3$ years old.

** a, b, c, d, e, f, g indicated the results of Duncan's multiple comparison tests.

Table 3. Infants' dimensions, age group and percentiles

(age under one month, $3.3 \mathrm{~kg}$ ), subgroup 2 (1-3 months, $5.4 \mathrm{~kg})$, subgroup 3 (3-5 months, (6.9 $\mathrm{kg})$, 5-7 months $(7.2 \mathrm{~kg})$ ), subgroup 4 (7-9 months, $8.1 \mathrm{~kg})$, subgroup 5 (9-12 months, $9 \mathrm{~kg})$, subgroup 6 (1-2 years, $10.9 \mathrm{~kg})$, and subgroup 7 (2-3 years old, $13 \mathrm{~kg})$. The means and standard deviations and infant-dimension percentiles by age group are presented in Table 3 .

\subsubsection{Sizing system of diapers}

Each figure type was classified into several size subgroups based on the control dimensions and size interval. The waist circumference and stature were chosen to represent the control dimensions. Furthermore, the categories of sizing systems could be denoted the seven subgroups by waist circumference and stature. Figure 2 showed that the distribution graph of stature versus waist circumference for seven categories. The waist types could be divided into four types (i.e. thin, medium, slight plump, and plump). In addition, stature could be divided into three types (i.e. short, medium, and tall). A total of $91 \%$ of samples have been fit on proposed sizing system (Table 4).

\begin{tabular}{ccccc}
\hline Sizing systems & categories & $\begin{array}{c}\text { Waist } \\
\text { Circumference } \\
(\mathrm{cm})\end{array}$ & $\begin{array}{c}\text { Stature } \\
(\mathrm{cm})\end{array}$ & Percent \\
\hline 1 & Thin-Short & $<36$ & $<56$ & $4.3 \%$ \\
\hline 2 & Medium-Short & $36.1-42$ & $<56$ & $6.3 \%$ \\
\hline 3 & Medium-Medium & $36.1-42$ & $56.1-73$ & $18.7 \%$ \\
\hline 4 & Slight plump-Medium & $42.1-48$ & $56.1-73$ & $9.0 \%$ \\
\hline 5 & Slight plump-Tall & $42.1-48$ & $>73.1$ & $6.7 \%$ \\
\hline 6 & Plump-Medium & $>48.1$ & $56.1-73$ & $23.0 \%$ \\
\hline 7 & Plump-Tall & $>48.1$ & $>73.1$ & $23.0 \%$ \\
\hline
\end{tabular}

Table 4. Sizing system of diapers for infants 


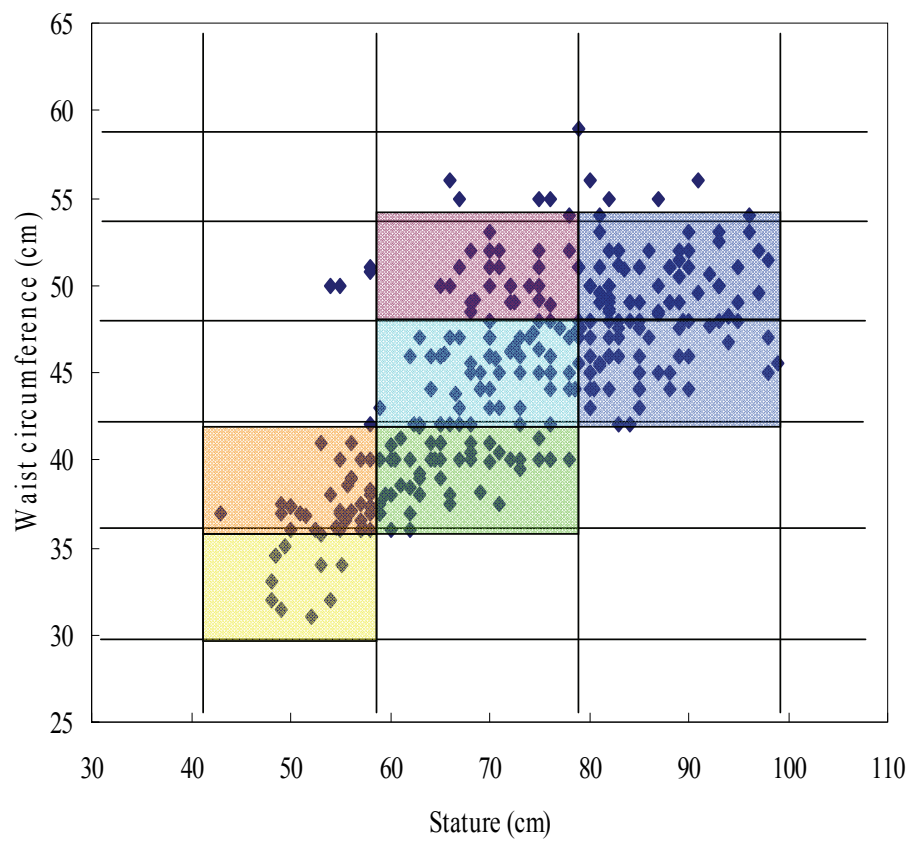

Fig. 2. The distribution graph of stature versus waist circumference for seven categories

\subsection{Discussion and conclusions}

Present study recorded the dimensions involved stature, weight, including head circumferences, waist circumferences, buttocks circumferences and thigh circumferences from three hundred subjects who aged from newborn to 3 years old were separated into eight stratifications (i.e. under one month, 1-3 months, 3-5 months, 2-7 months, 7-9 months, 9-12 months, 1-2 years, and 2-3 years old). One-way analysis of variance (ANOVA) was used to investigate the effects of age on dimensions of babies. As expected, the results showed that all dimensions were significant age effect. After Duncan's multiple range tests, these dimensions could be stratified six subgroups. However, diapers in the marketplace only have few sizes and classified according age and weight. From questionnaires survey (Lien et al., 2004) revealed that picking the well-suited diaper is more difficult for infants' parents, because the diaper sizes system only labeled the infants' age and weight. However, critical dimensions of the diaper (pants) should be circumferences of waist and buttocks. These are just one-third subjects satisfied with diaper design (Lien et al., 2004). For worse case, even if infants' age and stature in one size, we can't be sure diaper well-suitable for their circumferences of waist, buttocks and thigh. In addition, infants wore the wrong size of diaper, and it is a marked increase in risk of rash. Thus, present study could provide the anthropometric database for infants to redesign the new diaper size. Secondly, apart from infants' age and stature, circumferences of waist should be addressed and referenced. Suggestion of present study showed that each figure type was classified into several size 
subgroups based on the control dimensions and size interval. The waist circumference and stature were chosen to represent the control dimensions.

\section{Case 2: Spoon design for 3-12 year-old children}

\subsection{Introduction}

Carruth and Skinner (2002) reported at 12 months 43\% of children were self-feeding with spoons, and $43 \%$ of mothers had special spoons that their children used. As early as 10 months of age the children were making hand and body movements indicating their desire to eat from the table and especially their parents' plates (Skinner et al., 1998). By 24 months, $80 \%$ of the study children were self-feeding. The children's transition from using specific types of baby spoons to adult spoons began around 16 months of age with over $54 \%$ using adult spoons at 24 months. The type of spoon chosen by mothers may reflect their children's ability to grasp a spoon using thumb and fingers to pick up and hold a spoon (palm down) compared to the ability to hold a spoon like a pencil (first two fingers and thumb with palm turned up or towards face). At a mean age of 14.37 months, the children could bring the side of a spoon to their mouth, but within the same age range they also were using their fingers to self-feed. The age of transition from special baby spoon to adult spoon may be associated with the child's receiving food from the parent's plate (using adult spoons) which would provide a differing sensory experience than a child's special spoon. Thus, eating and drinking utensils need design for users associated with motor development.

Use of chopsticks is well known to Chinese. Use of chopsticks for the pleasure of enjoying a meal within either a family or a social context is deeply conceived in the heart of Chinese culture. Chinese children begin using chopsticks at about the age (standard deviation) of 4.6 years (1.13) and throughout life chopsticks are the preferred eating utensils (Wong et al., 2002). However, manipulating chopsticks requires fine-motor control and skills (Sandra, Donna, \& Jenna, 2002). Therefore, chopsticks users with children under 4 years old, or cervical spinal cord injury (SCI) or other types of hand impairments frequently are forced to switch to using spoons.

A spoon is a utensil consisting of a small shallow bowl, oval or round, at the end of a handle. It is used primarily for serving and eating liquid or semisolid food (sometimes called "spoon-meat"), and solid foods such as rice and cereal which cannot easily be lifted with a fork. Of course, eating utensils were also hand tools that require more precision or more force than a person's hand can safely sustain. Tool design can affect the user because the interface of the user with the tool will determine what the upper extremity and neck posture will be. Tools that create a need to abduct the elbow or shoulder to do a task will contribute to static muscle fatigue and limit the time the task can be sustained (Eastman Kodak, 1986). Thus, the purpose of this study was to determine the design factors preferred subjectively for choice of spoon. The second purpose was to observe the eating behavior and evaluate the design of spoon for children. It was expected that improved the eating comfortably and ensured the safety.

Apart from ethnic diversity, the most striking difference in body size is related to age. However, few studies have been conducted in the past to study on hand measurement for children particularly and were yet not being considered as an important parameter in the spoons design. Thus, the primary purpose of this study was to construct an anthropometric database about children for spoon design, and analyze it along with demographic data. The 
secondary aim of this research was to compare the dimensions of spoon in the marketplace with this anthropometric database and suggest the optimal dimensions.

\subsection{Methods}

\subsubsection{Participants}

Two hundred and five participants (96 boys and 109 girls) were accidental sampling from kindergarten and elementary school in Taipei and all participants were with no history of trauma or congenital anomalies on hands. The participants who age ranged from 3 to 12 years old were separated into eight stratifications for further analysis. The mean age of the sample population was 6.4 years $(\mathrm{sd}=8.1)$, mean stature $117.3 \mathrm{~cm}(\mathrm{sd}=10.4)$, and mean body mass $23 \mathrm{~kg}(\mathrm{sd}=14)$.

\subsubsection{Methodology of measurement}

The main instruments used in present survey were the electronic digital caliper and height measurement. An accuracy of $0.5 \mathrm{~mm}$ was the objective and all measurements were recorded in millimeters. Body weight was measured using a portable weighting scale $(\mathrm{kg})$. Altogether two anthropometric characteristics of hand were measured as follow:

a. Length of hand;

b. Breadth of hand;

\subsubsection{Data analysis}

All data were coded and summarized using SPSS software for Windows. Analysis of variance (ANOVA) was utilized to determine the effects of age on hand dimensions. Where statistically significant differences were determined, the Duncan post hoc test was performed. In addition, present study was to compare the dimensions of various spoons in marketplace products with this anthropometric database and suggest the optimal dimensions.

\subsection{Results}

\subsubsection{Effect of age on dimensions}

Mean stature and weight are presented in Table 5. All mean dimensions were significant differences between age groups $(p<0.001)$. Further, Duncan's post hoc tests revealed that mean stature could be divided into six subgroups, followed, in ascending order, by the subgroup 1 ( 3 years old; $99 \mathrm{~cm}$ ), subgroup 2 (4-6 years old; 106-111.4 cm), subgroup $3(7,8$ years old; $123.4-126.8 \mathrm{~cm}$ ), subgroup 4 (9 years old; $132.8 \mathrm{~cm})$, subgroup 5 (10 years old; $137.7 \mathrm{~cm})$ and subgroup 6 (11-12 years old ; 148-149 $\mathrm{cm})$.

In addition, Duncan's post hoc tests revealed that mean weight could be divided into five subgroups, followed, in ascending order, by the subgroup 1 (3-4 years old; 15-16.8 kg), subgroup 2 (4-6 years old; $16.8-19.6 \mathrm{~kg}$ ), subgroup 3 (7, 8 years old; $24.3-25.7 \mathrm{~kg}$ ), subgroup 4 (9-10 years old; $29.8-32.5 \mathrm{~kg}$ ), and subgroup 5 (11-12 years old; 41.8-44.1 kg).

Mean length and breadth are presented in Table 6. Duncan's post hoc tests revealed that mean length of hand could be divided into five subgroups, followed, in ascending order, by the subgroup 1 (3-4 years old; $106.4-106.8 \mathrm{~mm})$, subgroup 2 (5, 6, 8, 9 years old; 120.1-132 
$\mathrm{cm})$, subgroup 3 (7, 8, 9, 10 years old; 130.1-137.2 mm), subgroup 4 (7, 10, 12 years old; 136.1 $146.6 \mathrm{~mm}$ ) and subgroup 5 (11-12 years old; 146.6-157.6 mm).

Mean breadth of hand could be divided into seven subgroups, followed, in ascending order, by the subgroup 1 ( 3 , 4 years old; $49.66-52.29 \mathrm{~mm})$, subgroup $2(4,5,6$ years old; $552.3-57.2$ $\mathrm{mm})$, subgroup $3(7,8,9$ years old; 63.5-70.5 mm), subgroup $4(10,11$ years old; 75.8-76.4 $\mathrm{mm})$, subgroup 5 (10, 11 years old; 75.8-76.4 mm) and subgroup 6 (12 years old; $98.2 \mathrm{~mm}$ ).

\begin{tabular}{ccccc}
\hline & \multicolumn{2}{c}{ Stature $(\mathrm{cm})$} & \multicolumn{2}{c}{ Weight $(\mathrm{kg})$} \\
\hline Age groups & mean & SD & mean & SD \\
\hline 3 & 99.39 & 4.25 & 15.1 & 1.55 \\
\hline 4 & 106.0 & 4.29 & 16.8 & 2.41 \\
\hline 5 & 111.4 & 6.78 & 19.1 & 3.17 \\
\hline 6 & 109.7 & 7.92 & 19.7 & 3.46 \\
\hline 7 & 123.4 & 5.62 & 24.3 & 5.56 \\
\hline 8 & 126.8 & 5.16 & 25.7 & 5.70 \\
\hline 9 & 132.8 & 7.20 & 29.8 & 6.75 \\
\hline 10 & 137.7 & 6.51 & 32.5 & 6.81 \\
\hline 11 & 149.1 & 7.80 & 41.8 & 7.58 \\
\hline 12 & 148.2 & 5.33 & 44.1 & 8.92 \\
\hline
\end{tabular}

Table 5. Stature and weight by age groups

\begin{tabular}{ccccc}
\hline & \multicolumn{4}{c}{ Dimensions $(\mathrm{mm})$} \\
\cline { 2 - 5 } & \multicolumn{2}{c}{ Length of hand } & \multicolumn{2}{c}{ Breadth of hand } \\
\hline Age groups & mean & SD & mean & SD \\
\hline 3 & 106.4 & 7.76 & 49.7 & 3.60 \\
\hline 4 & 106.8 & 14.7 & 52.3 & 3.57 \\
\hline 5 & 121.8 & 9.31 & 57.2 & 4.32 \\
\hline 6 & 120.2 & 9.38 & 56.4 & 3.91 \\
\hline 7 & 136.2 & 6.43 & 63.4 & 5.78 \\
\hline 8 & 130.2 & 10.72 & 70.5 & 11.7 \\
\hline 9 & 132.1 & 17.4 & 67.3 & 6.33 \\
\hline 10 & 137.2 & 17.4 & 75.8 & 11.1 \\
\hline 11 & 157.6 & 6.96 & 76.4 & 12.6 \\
\hline 12 & 146.7 & 8.86 & 98.2 & 17.6 \\
\hline
\end{tabular}

Table 6. Hand dimensions by age groups

\subsubsection{Spoon design}

Present study provided product designer with the anthropometric dimensions of hand for children and recommend appropriate solutions for design. In addition, hand dimensions for 3-12 age children were showed in Table 6.

For Japanese data of hand length, these are about $100 \mathrm{~mm}, 110 \mathrm{~mm}, 120 \mathrm{~mm}, 130 \mathrm{~mm} 140$ $\mathrm{mm}, 150 \mathrm{~mm}, 160 \mathrm{~mm}$ for 2 years old, 3 years old, 4 years old, 5 years old, first-second grade elementary school, third-fourth grade elementary school, and fifth-sixth grade elementary school. The length of chopstick has determined on increase $30 \mathrm{~mm}$ from hand length. Thus, 
Japanese chopstick of length could be divided into eight various sizes for children. These are about $130 \mathrm{~mm}, 140 \mathrm{~mm}, 150 \mathrm{~mm}, 160 \mathrm{~mm} 170 \mathrm{~mm}, 180 \mathrm{~mm}, 190 \mathrm{~mm}$ for 2 years old, 3 years old, 4 years old, 5 years old, first-second grade elementary school, third-fourth grade elementary school, and fifth-sixth grade elementary school (Hashiseiwa Company, Japan). This is general principles for applying anthropometric data to specific design problems. Certain features of equipment or facilities can be designed so they can be adjusted to the individuals who use them. Thus, the length of spoon should be adjustable from $136 \mathrm{~mm}$ to $187 \mathrm{~mm}$. Five levels could be set on adjustable length .In addition, open windows could see the indicator of length (Figure 3).

According the principles of hand tool and device design (Fraser, 1980; Freivalds 1987), tools should be designed to be used in the operator's preferred hand. For example, the handle could be moved for left-handed use, if a threaded fastener were provided in the right side of the drill housing (Greenberg \& Chaffin, 1977). So, spoon design for right-hand or left-hand user should be considered for convenient. Thus, the prototype of new spoon for children showed in Figure 4. The shallow bowl of present spoon could be turned to right or left and could decrease the wrist radius deviation.

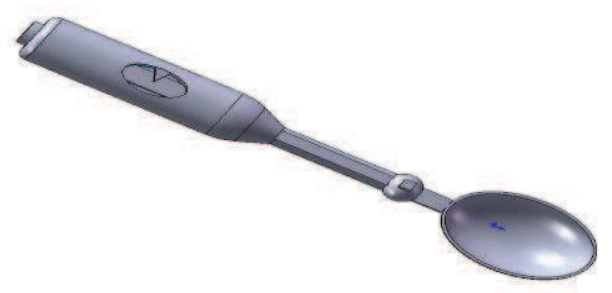

Fig. 3. The length of spoon also adjusted from $136 \mathrm{~mm}$ to $176 \mathrm{~mm}$ by rotating the back button
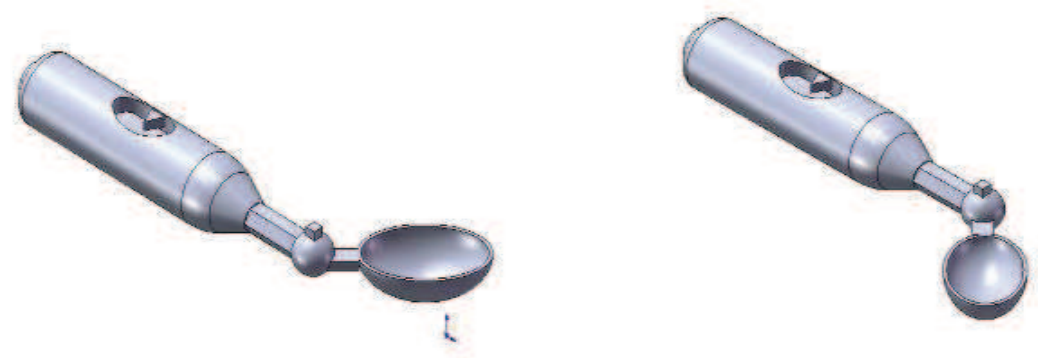

Fig. 4. New spoon could turn the shallow bowl to right and left side

\subsection{Discussion and conclusion}

Tool design can affect the user because the interface of the user with the tool will determine what the upper extremity and neck posture will be. Tools that create a need to abduct the 
elbow or shoulder to do a task will contribute to static muscle fatigue and limit the time the task can be sustained (Eastman Kodak, 1986). Hsu and Wu (1991) investigated the effects of the length of chopsticks on the food-servicing performance. Their results showed that the food-pinching performance was significantly affected by the length of the chopsticks, and the chopsticks of about 240 and $180 \mathrm{~mm}$ long were optimal for adults and pupils, respectively. Chen, Liu and Tseng (2009) examined the effects of age, chopsticks characteristics and pinching tasks on performance and subjective ratings. Thirty elementary school students were recruited in present study and divided into three groups $(8,10$ and 12 years old). Eight types of chopsticks had been evaluated on pinching two objects (corn snacks and chocolate balls). Results of ANOVA showed that the pinching performance was significant difference between ages. In addition, the pinching performance was better in applying the hexagon chopstick with particular length. By contrast, the stainless steel chopstick was worse case. Therefore, manufacturers should make products available in various sizes to accommodate different users at least four sizes for children and various sizes of spoons were based on hand length plus $30 \mathrm{~mm}$.

\section{References}

Ashdown, S. P. (1998). An investigation of the structure of sizing systems. International Journal of Clothing Science Technology, 10, 324-341.

Borkowski, S. (2004). Diaper rash care and management. Pediatric Nursing, 30(6), 467-470.

Carruth, B. R., \& Skinner, J. D. (2002). Feeding behaviors and other motor development in healthy children (2-24 months). Journal of the American College of Nutrition, 21(2), 88-96.

Chung, M. J., Lin, H. F., \& Wang, M. J. (2007). The development of sizing systems for Taiwanese elementary-and high-school students. International Journal of Industrial Ergonomics, 37, 707-716.

Eastman Kodak Company, Ergonomics Group, Health and Environment Laboratories (1986). Ergonomic Design for People at Work, vol. 2. New York: Van Nostrand Reinhold.

Emanuel, I., Alexander, M., Churchill, E., \& Truett, B. (1959). A height-weight sizing system for flight clothing. In. WADC Technical Report 56-365, Wright Air Development Center (Ohio: Wright-Patterson Air Force Base).

Fraser, T. (1980). Ergonomic principles in the design of hand tools, Occupational Safety and Health Series no. 44. Geneva, Switzerland: International Labour Office.

Freivalds, A. (1987). The ergonomics of tools. In D. Oborne, (ed.), International reviews of ergonomics, vol. 1. London: Taylor \& Francis.

Gorgos, D. (2006). Underlying disorder may cause diaper dermatitis. Dermatology Nursing, 18,501 .

Greenberg, L., \& Chaffin, D. (1977). Workers and their tools. Midland, MI: Pendell Publishing.

Hsu, C. H., Liu, B. S., \& Chen, S. C. (2007). Using systematic approach to discover sizing knowledge from anthropometric data for improving production. WSEAS Transactions on Systems, 6(4), 852-857.

Hsu, S. H., \& Wu, S. P. (1991). An investigation for determining the optimum length of chopsticks, Applied Ergonomics, 22(6), 395-400.

Jackson, E. M. (1995). Diaper Rash Products: A Review. American Journal of Contact Dermatitis, 6, 236-239. 
Jorden, W. E., Larson, K. D., Berg, R. W., Frandman, J. J., \& Marrer, A. M. (1986). Diaper dermatitis: Frequency and severity among a general infant population. Pediatric Dermatology, 3, 198-207.

Kubiak, M., Kressner, B., Raynor, W., Davis, J., \& Syverson, R. E. (1993). Comparison of cloth and single use diapers using a simulated infant faces. Pediatrics, 91, 632-636.

Li, Z. (2006). Anthropometric Topography. In International Encyclopedia of Ergonomics and Human Factors, In W. Karwowski, (eds.). London, UK: Taylor \& Francis.

Lien, C. W., Liu, B. S., Huang, S. Y., Huang, X. H. and Kang, S. H. (2004). Survey of Baby Diaper Design. In Proceedings of the 2004 Annual Conference on Ergonomics Society of Taiwan. In H. Wang, (eds.). Da-Yeh University, Changhua, Taiwan. (in Chinese)

Liptak, G. S. (2001). Diaper rash. In Pediatric primary care, edited by Heekelman et al., pp. 1225-1228.

Meunier, P., \& Yin, S. (2000). Performance of a 2D Image-based Anthropometric Measurement and Clothing Sizing System. Applied Ergonomics, 31, 445-451.

Milanese, S., \& Grimmer, K. (2004). School Furniture and the User Population: An Anthropometric Perspective. Ergonomics, 47, 416-426.

Mououdi, M. A. (1997). Static anthropometric characteristics of Tehran university students age 20-30. Applied Ergonomics, 28, 149-150.

Niu, J., Li, Z., \& Salvendy, G. (2006). Multi-resolution Description of 3D Anthropometric Data. Proceedings of the 16th World Congress on Ergonomics, International Ergonomics Association.

Ray, G., Ghosh, S., \& Aterya, V. (1995). An anthropometric survey of Indian schoolchildren age 3-5 years. Applied Ergonomics, 26, 67-72.

Sanders, M. S., \& McCormick, E. J. (1993). Human Factors in Engineering and Design, 7th ed. New York: McGraw-Hill.

Sandra, J., Donna, J., \& Jenna, D. (2002). Developmental and functional hand grasps: precision grasps. Thorofare: Slack, 108-109.

Skinner, J., Carruth, B. R., Houck, K., Moran, III J, Reed, A., Coletta, F., \& Ott, D. (1998). Mealtime communication patterns of infants from 2 to 24 months of age. Journal of Nutrition Education, 30, 8-16.

Van Onselen, J. (1999). Rash advice. Nursing Times Skin Care, 12.

Van, R., Wun, C. C. Morrow, A.L., \& Pickering, L. K. (1991). The effect of diaper type and overclothing on fecal containment in day care centers. Journal of American Medical Association, 265, 1840-1844.

Wang, E. M. Y., Wang, M. J., Yeh, W. Y., Shih, Y. C., \& Lin, Y. C. (1999). Development of anthropometric work environment for Taiwan workers. International Journal of Industrial Ergonomics, 23, 3-8.

Wickens, C.D., Lee J.D., Liu, Y., \& Gordon-Becker, S.E. (2004). An Introduction to Human Factors Engineering, 2nd ed. Upper Saddle River, New Jersey: Pearson Education.

Wolf, R., Wolf, D., Tuzun, B., \& Tuzun, Y. (2000). Diaper Dermatitis. Clinics in Dermatology, 18, 657-660.

Wong, S., Chan, K., Wong, V., \& Wong, W. (2002). Use of chopsticks in Chinese children. Child: Care, Health \& Development, 28(2), 157-161.

Wysocki, B. A., \& Bryant, A. R. (1992). Skin. In Acute and chronic wounds nursing management, In A. R. Bryant (eds.). St. Louis: Mosby Yearbook, pp. 1-30. 


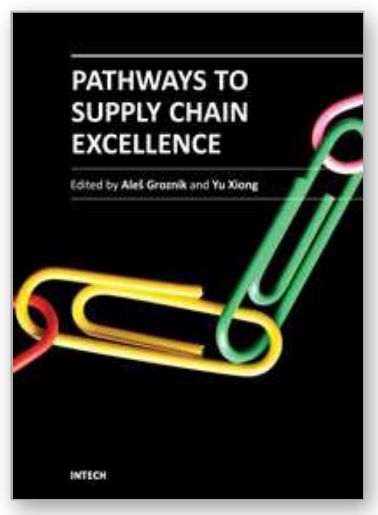

\author{
Pathways to Supply Chain Excellence \\ Edited by Dr. Ales Groznik
}

ISBN 978-953-51-0367-7

Hard cover, 208 pages

Publisher InTech

Published online 16, March, 2012

Published in print edition March, 2012

Over the last decade, supply chain management has advanced from the warehouse and logistics to strategic management. Integrating theory and practices of supply chain management, this book incorporates hands-on literature on selected topics of Value Creation, Supply Chain Management Optimization and MassCustomization. These topics represent key building blocks in management decisions and highlight the increasing importance of the supply chains supporting the global economy. The coverage focuses on how to build a competitive supply chain using viable management strategies, operational models, and information technology. It includes a core presentation on supply chain management, collaborative planning, advanced planning and budgeting system, risk management and new initiatives such as incorporating anthropometry into design of products.

\title{
How to reference
}

In order to correctly reference this scholarly work, feel free to copy and paste the following:

Bor-Shong Liu and Ching-Wen Lien (2012). Incorporating Anthropometry into Design of Products, Pathways to Supply Chain Excellence, Dr. Ales Groznik (Ed.), ISBN: 978-953-51-0367-7, InTech, Available from: http://www.intechopen.com/books/pathways-to-supply-chain-excellence/incorporating-anthropometry-intodesign-of-products

\section{INTECH}

open science | open minds

\author{
InTech Europe \\ University Campus STeP Ri \\ Slavka Krautzeka 83/A \\ 51000 Rijeka, Croatia \\ Phone: +385 (51) 770447 \\ Fax: +385 (51) 686166 \\ www.intechopen.com
}

\author{
InTech China \\ Unit 405, Office Block, Hotel Equatorial Shanghai \\ No.65, Yan An Road (West), Shanghai, 200040, China \\ 中国上海市延安西路65号上海国际贵都大饭店办公楼 405 单元 \\ Phone: +86-21-62489820 \\ Fax: +86-21-62489821
}


(C) 2012 The Author(s). Licensee IntechOpen. This is an open access article distributed under the terms of the Creative Commons Attribution 3.0 License, which permits unrestricted use, distribution, and reproduction in any medium, provided the original work is properly cited. 